\title{
SIFAT FISIK, KIMIA, DAN MORFOLOGIK KULIT JAKET KAMBING TERSAMAK MENGGUNAKAN KROM HASIL RECOVERY AIR LIMBAH PENYAMAKAN
}

\section{PHYSICAL, CHEMICAL, AND MORPHOLOGICAL PROPERTIES OF TANNED GOAT JACKET LEATHER USING RECOVERED CHROME FROM TANNING WASTE WATER}

\author{
Sri Sutyasmi \\ Balai Besar Kulit, Karet, dan Plastik, J1. Sokonandi No. 9, Yogyakarta 55166, Indonesia \\ Telp.: +62 274 512929, 563939; Fax.: +62 274563655 \\ E-mail: srisutyasmi@ymail.com
}

Diterima: 9 Juni 2015 Direvisi: 20 Oktober 2015 Disetujui: 19 November 2015

\begin{abstract}
The purpose of this study was to recover chrome in tanning waste water to reduce environmental pollution and to utilize chrome as tanning agent. Chrome in tanning waste water leaching out of the drum was filtered and put in the tank and subsequently it was added with $\mathrm{NaOH}$ to generate chrome hydroxide. Furthermore, chrome hydroxide was converted to chrome sulfate as tanning agent by addition of concentred sulfuric acid. $\mathrm{Cr}_{2} \mathrm{O}_{3}$ content of chrome sulfate was determined before being used for tanning. The result showed that $\mathrm{Cr}_{2} \mathrm{O}_{3}$ content was 3958.6 $\mathrm{mg} / \mathrm{l}$. Variation of recovered chrome sulfate concentrations for tanning jacket leather were 25, 50, 75 and 100\% respectively. Controls were made with the use of $100 \%$ of industrial grade chrome sulfate. The best result were goat jacket leather tanned with recovered chrome of 75 and $100 \%$ for its physical properties and $25 \%$ for its chemical properties. Test results of SEM showed that chrome was morphologically presence in tanned goat leather mass.
\end{abstract}

Keywords: tanning, jackets leather, chrome recovery, physical and chemical properties, leather morphology.

\begin{abstract}
ABSTRAK
Tujuan dari penelitian ini adalah mengambil kembali krom dalam air limbah penyamakan krom untuk mengurangi pencemaran lingkungan dan menghemat pembelian puder krom sebagai bahan penyamak krom. Air limbah penyamakan krom yang keluar dari drum, disaring dan dimasukkan dalam tangki dan ditambah $\mathrm{NaOH}$ untuk diendapkan menjadi krom hidroksida. Selanjutnya krom hidroksida dialirkan ke tangki yang lain dan ditambahkan asam sulfat pekat menjadi krom sulfat yang digunakan untuk menyamak. Hasil diuji kadar $\mathrm{Cr}_{2} \mathrm{O}_{3}$ terlebih dahulu sebelum digunakan untuk menyamak. Hasil uji kadar $\mathrm{Cr}_{2} \mathrm{O}_{3}$ adalah rata-rata sebesar $3958,6 \mathrm{mg} / \mathrm{l}$. Variasi konsentrasi krom sulfat hasil recovery untuk penyamakan kulit jaket berturut-turut $25,50,75$, dan $100 \%$. Krom sulfat pasaran dengan konsentrasi $100 \%$ digunakan sebagai kontrol. Hasil uji sifat fisis kulit jaket kambing terbaik adalah konsentrasi krom berturut-turut 75 dan $100 \%$ dan untuk sifat kimia kulit jaket terbaik $25 \%$ yang disamak dengan krom sulfat hasil recovery. Hasil uji SEM menunjukkan bahwa secara morfologi krom dijumpai dalam kulit tersamak.
\end{abstract}

Kata kunci: penyamakan, kulit jaket, chrome recovery, sifat fisik dan kimia, morfologi kulit.

\section{PENDAHULUAN}

Perkembangan industri penyamakan kulit di Indonesia berdampak pada peningkatan jumlah limbah yang dihasilkan, baik limbah cair maupun limbah padat. Bahkan perkembangan tersebut juga diikuti oleh kenaikan resiko dengan meningkatnya jumlah limbah dari penyamakan kulit yang dihasilkan (Harmami et al., 2014). Industri penya- makan kulit mengolah kulit mentah (hides atau skins) menjadi kulit tersamak (leather) dengan menggunakan bahan penyamak, dan dari bahan penyamak tesebut akan dihasilkan limbah cair. Ditinjau dari jenis bahan penyamak yang dipakai, maka terdapat beberapa cara penyamakan yaitu (1) penyamakan nabati, (2) penyamakan mineral, dan (3) penyamakan minyak (Dettmer et al. 2010). 
Bahan penyamak jenis senyawa krom digunakan untuk penyamakan kulit yang di kelompokkan sebagai penyamakan mineral. Kandungan krom dalam limbah yang keluar dari drum penyamakan kulit relatif tinggi yang diindikasikan oleh warna limbah yang gelap. Selain mencemari lingkungan, senyawa krom merupakan bahan beracun dan berbahaya (B3), maka krom juga menggangu pengolahan limbah cair khususnya pada pengolahan limbah cair sistem biologi (Fuck et al., 2011; Hyder, 2013; Bestawy et al., 2013). Senyawa kromium $(\mathrm{Cr})$ dalam limbah cair industri penyamakan kulit berasal dari unit penyamakan kulit, yang menggunakan senyawa krom sulfat antara dengan konsentrasi $60-70 \%$. Krom sulfat tersebut tidak seluruhnya dapat diserap oleh kulit saat penyamakan berlangsung dengan demikian sisanya dikeluarkan dalam bentuk limbah cair (Harmami et al., 2014). Keberadaan senyawa krom kadar tinggi dalam limbah cair industri penyamakan kulit berdampak pada pencemaran lingkungan (Mutlu et al., 2014).

Senyawa krom bersifat karsinogenik, menimbulkan gatal, iritasi dan inflamasi pada kulit dan selaput lendir, serta mencemari lingkungan (Christianna et al., 2013; Belay, 2010). Oleh karena itu diperlukan upaya pemanfaatan limbah cair penyamakan kulit tersebut melalui proses recovery krom (Wardhani et al., 2013; Bestawy et al., 2013).

Senyawa krom pada limbah cair penyamakan kulit perlu diperoleh kembali (recovery) mengingat (1) krom dalam limbah cair mengandung krom trivalen relatif tinggi, (2) senyawa krom limbah cair dari penyamakan kulit berkisar 1000050000 ppm (Sundar, 2011). Menurut Ludvik (2000), konsentrasi asam sulfat yang dicapai untuk recovery krom $\mathrm{pH}$ larutan adalah 2,0-2,8. Larutan yang diperoleh dianalisis kandungan krom(III)nya untuk menentukan tingkat efektivitas recovery (Belay, 2010). Proses pengendapan krom(III) dari limbah cair akan lebih efektif jika dikerjakan pada $\mathrm{pH}$ larutan $=8$ dengan persentase efisiensi recovery $=52 \%$, sedangkan waktu pengendapan yang optimal adalah 24 jam dengan persentase efisiensi recovery sebesar 77,63\%. (Hastutiningrum, 2010). Pelarutan kembali endapan krom(III) yang diperoleh agar dapat digunakan kembali sebagai bahan penyamak krom menggunakan asam sulfat pekat (El-Sabbagh \& Mohamed, 2011).

Pengenapan krom yang optimal adalah 24 jam dengan persentase efisiensi recovery sebesar
77,63\%. Pelarutan kembali endapan krom(III) yang diperoleh dengan menggunakan asam sulfat dimaksudkan agar dapat digunakan kembali sebagai bahan penyamak krom (Mukherjee et al., 2010)

Tujuan penelitian ini adalah mengambil kembali krom dari limbah cair penyamakan krom untuk mengurangi potensi pencemaran lingkungan dan pemanfaatan kembali krom hasil recovery penyamakan kulit serta mengetahui sifat fisik, kimia an morfologi kulit yang dihasilkan.

\section{BAHAN DAN METODE \\ Bahan Penelitian}

Bahan penelitian adalah kulit kambing, limbah cair krom dari drum penyamakan, asam sulfat teknis, $\mathrm{NaOH}$, dan bahan kimia untuk pengujian krom.

\section{Peralatan penelitian}

Peralatan untuk penelitian terdiri atas satu unit perangkat recovery krom dan drum eksperimen penyamak kulit dengan kapasitas $850 \mathrm{~kg}$.

Alat untuk pengujian fisik seperti kuat tarik, kemuluran, dan kuat sobek menggunakan Material Testing Zwick/Roell 2020 model 2007, alat untuk pengujian tebal SG 300, alat untuk pengujian penyamakan suhu kerut, Softness Tester ST 300, dan alat untuk uji tembus uap air menggunakan Water Permeability Tester STM 473.

Alat untuk pengujian kimia terdiri atas $\mathrm{pH}$ meter merk Toledo, kadar air menggunakan Deanstark Apparatus, kadar abu menggunakan Furnace NEY M 525 Series II, kadar lemak menggunakan Soxlet, labu dan electromantel, dan pemeriksaan krom menggunakan metode yodometri yaitu menggunakan titrasi.

Alat uji yang digunakan untuk uji Morfologi adalah Scaning Electron Microscopy (SEM) JEOL-JSM-6510 LV.

\section{Metode Penelitian}

Limbah cair dari drum penyamakan krom disaring dan dimasukkan dalam rangkaian alat untuk recovery krom, selanjutnya, krom yang ada dalam limbah tersebut diambil kembali. Rangkaian tersebut terdiri atas tangki penampung krom, tangki $\mathrm{NaOH}$ jenuh, tangki koagulasi dan pengendap, tangki asam sulfat pekat, tangki pencampur endapan krom dengan asam sulfat pekat dan tangki penampung krom sulfat. Urutan kerja recovery krom tersebut seperti disajikan pada Gambar 1. 


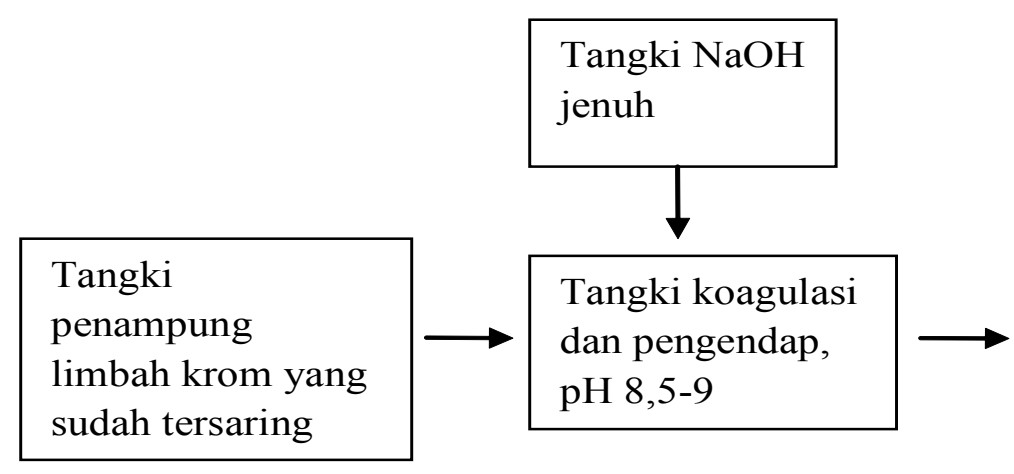

Gambar 1. Diagram alir proses krom recovery senyawa krom.

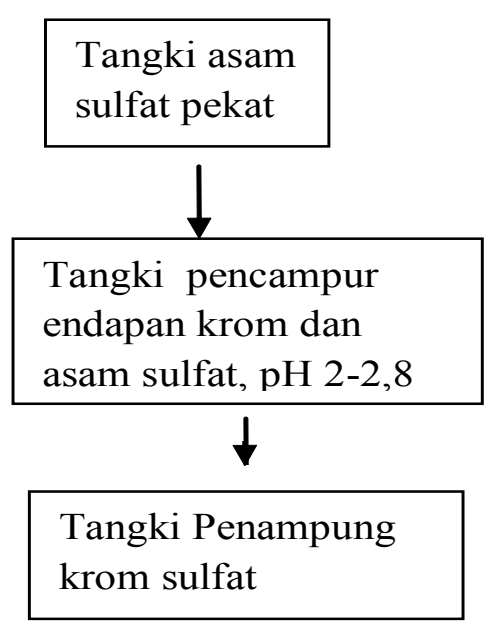

Selanjutnya krom sulfat yang dihasilkan diuji kadar $\mathrm{Cr}_{2} \mathrm{O}_{3}$ nya untuk menentukan berapa liter tiap kg kulit krom sulfat yang digunakan untuk menyamak kulit jaket.

Krom yang digunakan untuk menyamak kulit adalah $6 \%$, sedangkan variasi penyamakan krom sulfat yang digunakan untuk menyamak kulit adalah $25,50,75$, dan $100 \%$ dari $6 \%$ puder krom/ murni yang digunakan. Kontrol dibuat dari $100 \%$ krom murni. Kulit jaket diuji sifat fisis, kimia sesuai dengan SNI 4593:2011, yaitu SNI untuk kulit jaket domba/kambing. Selain itu juga diuji SEM dari kulit jaket tersebut untuk mengetahui morfologi kulit jaket yang disamak dengan krom hasil recovery.

\section{HASIL DAN PEMBAHASAN Krom Hasil Recovery}

Krom hasil recovery yang akan digunakan untuk penyamakan kulit jaket adalah sebagai berikut. Kandungan krom limbah cair yang keluar dari drum penyamakan kulit sebesar 3.998,6 $\mathrm{mg} / \mathrm{l}$. Kandungan krom hasil recovery dalam krom sulfat sebesar 3.672,4 mg/l. Perhitungan penggunaan krom recovery untuk penyamakan kulit didasarkan pada bobot kulit dan jumlah krom untuk penyamakan kulit ( $\%$ dari bobot kulit). Persentase krom murni yang digunakan untuk penyamakan sudah diketahui, sehingga dapat diketahui berapa $\mathrm{kg}$ krom yang digunakan. Selanjutnya $\mathrm{Cr}_{2} \mathrm{O}_{3}$ olahan dikalikan dengan jumlah $\mathrm{Cr}_{2} \mathrm{O}_{3}$ untuk penyamakan.

\section{Hasil Uji Sifat Fisik}

Hasil uji siat fisis kulit jaket kambing dapat dilihat pada Tabel 1. Tabel 1 menunjukkan bahwa sifat fisik kulit jaket yang disamak dengan krom sulfat hasil recovery limbah cair samak krom, maka parameter tebal dan kekuatan sobek memenuhi ketentuan SNI 4593:2011 untuk kulit jaket domba/kambing. Sedangkan parameter penyamakan yang memenuhi SNI 4593:2011 adalah penyamakan dengan 75 dan $100 \%$ krom sulfat hasil recovery. Kulit samak krom dikatakan masak atau matang bila kulit tersebut telah tersamak sempurna. Tanda-tanda kulit tersamak sempurna adalah kulit mengalami pengerutan saat dimasukkan ke air mendidih selama 3-5 menit atau boiling test.

Untuk parameter kekuatan tarik yang memenuhi SNI 4593:2011 adalah kulit yang disamak dengan konsentrasi 25 dan 100\% krom sulfat hasil recovery. Sedangkan parameter kemuluran yang memenuhi persyaratan SNI 4593:2011 adalah kulit hasil penyamakan dengan konsentrasi krom hasil recovery 75 dan $100 \%$. Pada parameter tembus uap air dan kelemasan, semua perlakuan percobaan memenuhi SNI 4593:2011.

Dengan demikian dapat disimpulkan bahwa penyamakan terbaik yang memenuhi SNI 4593:2011 adalah kulit jaket samak krom dengan konsentrasi 75 dan $100 \%$. Hal ini ditunjukkan oleh parameter fisik yang diuji semuanya memenuhi persyaratan. Sedangkan kontrol (penggunaan krom murni $100 \%$ ) justru tidak memenuhi persyaratan SNI4593:2011 (SNI kulit jaket domba/kambing). Dimungkinkan hal ini sangat tergantung proses penyamakannya. Hal ini dapat terjadi karena pemberian serbuk krom tidak sesuai ukuran yaitu kadar $\mathrm{Cr}_{2} \mathrm{O}_{3}$ tidak diperhitungkan. Kadar $\mathrm{Cr}_{2} \mathrm{O}_{3}$ dalam senyawa krom sebesar $25 \%$, sehingga apabila penyamakan kulit mengguna- 
kan krom $6 \%$, maka seharusnya senyawa krom untuk penyamakan kulit adalah setara dengan 25 $/ 100$ × $6 \%$ yaitu sebesar $1,5 \%$.

\section{Hasil Uji Sifat Kimia}

Hasil uji sifat kimia kulit jaket dari penyamakan dengan krom hasil recovery dapat dilihat pada Tabel 2. Tabel 2 menunjukkan bahwa kadar air kulit tersamak memenuhi persyaratan SNI 4593:2011 untuk kulit jaket domba/kambing. Sedangkan hasil uji krom oksida menunjukkan bahwa semua perlakuan tidak memenuhi syarat SNI 4593:2011. Hal ini kemungkinan karena penggunaan krom hasil recovery tidak didasarkan pada kadar $\mathrm{Cr}_{2} \mathrm{O}_{3}$ dalam krom sulfat hasil recovery seperti yang diutarakan di atas. Dengan demikian

Tabel 1. Hasil uji siat fisis kulit jaket samak krom hasil recovery.

\begin{tabular}{|c|c|c|c|c|}
\hline Parameter Uji & $\begin{array}{l}\text { Kode } \\
\text { sampel }\end{array}$ & Hasil uji & Metode uji & $\begin{array}{l}\text { SNI Kulit jaket domba/ } \\
\text { kambing }\end{array}$ \\
\hline \multirow[t]{5}{*}{ Tebal, mm } & 1 & 0,60 & \multirow[t]{5}{*}{ SNI 06-7128-2005 } & \multirow[t]{5}{*}{$0,4-0,8$} \\
\hline & 2 & 0,52 & & \\
\hline & 3 & 0,52 & & \\
\hline & 4 & 0,48 & & \\
\hline & 5 & 0,56 & & \\
\hline \multirow[t]{5}{*}{ Kekuatan sobek, N/mm } & 1 & 21,89 & \multirow[t]{5}{*}{ SNI 06-1794-1990 } & \multirow[t]{5}{*}{ Min 12,5 } \\
\hline & 2 & 20,72 & & \\
\hline & 3 & 18,72 & & \\
\hline & 4 & 27,12 & & \\
\hline & 5 & 20,71 & & \\
\hline Penyamakan, & 1 & 21,89 & \multirow[t]{5}{*}{ SNI 06-0253-1989 } & \multirow[t]{5}{*}{ Maks 10} \\
\hline \multirow[t]{4}{*}{$\%$ penyusutan } & 2 & 20,71 & & \\
\hline & 3 & 10,03 & & \\
\hline & 4 & 5,31 & & \\
\hline & 5 & 20,71 & & \\
\hline \multirow{5}{*}{ Kekuatan tarik, $\mathrm{N} / \mathrm{mm}^{2}$} & 1 & 17,63 & \multirow{5}{*}{ SNI 06-1795-1990 } & \multirow[t]{5}{*}{ Min 14} \\
\hline & 2 & 10,08 & & \\
\hline & 3 & 10,50 & & \\
\hline & 4 & 14,99 & & \\
\hline & 5 & 13,42 & & \\
\hline \multirow[t]{5}{*}{ Kemuluran, \% } & 1 & 78,88 & \multirow[t]{5}{*}{ SNI 06-1795-1990 } & \multirow[t]{5}{*}{ Maks 60} \\
\hline & 2 & 67,83 & & \\
\hline & 3 & 59,13 & & \\
\hline & 4 & 59,12 & & \\
\hline & 5 & 92,23 & & \\
\hline \multirow{5}{*}{$\begin{array}{l}\text { Tembus uap air, mg/cm²/ } \\
\text { jam }\end{array}$} & 1 & 15,29 & \multirow[t]{5}{*}{ ISO 5403;2002 } & \multirow[t]{5}{*}{$\operatorname{Min} 2,50$} \\
\hline & 2 & 9,88 & & \\
\hline & 3 & 10,06 & & \\
\hline & 4 & 8,64 & & \\
\hline & 5 & 6,20 & & \\
\hline \multirow{5}{*}{$\begin{array}{l}\text { Kelemasan }\left(\begin{array}{lll}\Phi & 20 & \mathrm{~mm}\end{array}\right) \\
\mathrm{mm}\end{array}$} & 1 & 5,93 & \multirow[t]{5}{*}{ SNI ISO 17235:2002 } & \multirow[t]{5}{*}{$5,0-7,6$} \\
\hline & 2 & 6,00 & & \\
\hline & 3 & 5,43 & & \\
\hline & 4 & 5,80 & & \\
\hline & 5 & 6,20 & & \\
\hline
\end{tabular}

Keterangan kode sampel:

$1=$ Kulit jaket dengan konsentrasi $25 \%$ krom sulfat hasil recovery

$2=$ Kulit jaket dengan konsentrasi $50 \%$ krom sulfat hasil recovery

$3=$ Kulit jaket dengan konsentrasi $75 \%$ krom sulfat hasil recovery

$4=$ Kulit jaket dengan konsentasi $100 \%$ krom sulfat hasil recovery

$5=$ Kulit jaket dengan konsentrasi $0 \%$ krom recovery (kontrol) 
kadar krom kulit jaket melebihi ketentuan syarat mutu SNI 4593:2011 untuk kulit jaket domba/ kambing. Kadar abu kulit jaket samak krom yang memenuhi syarat mutu SNI 4593:2011 adalah kulit jaket dengan konsentrasi 25\% krom hasil recovery. Sedangkan kadar lemak/minyak kulit jaket kambing hasil samak krom untuk semua konsentrasi memenuhi syarat mutu SNI 4593:2011. Hasil uji $\mathrm{pH}$ dari kulit jaket samak krom semua variasi memenuhi SNI 4593:2011.

Sutyasmi \& Supraptiningsih (2014) menyatakan bahwa penyamakan krom melalui empat tahapan reaksi yang terjadi secara bersamaan. Reaksi tersebut antara ligan koordinasi pada kromium kompleks. Dengan pengaturan kondisi
$\mathrm{pH}$, suhu, dan konsentrasi senyawa krom maka dominasi dari masing-masing reaksi dapat dikendalikan. Keempat reaksi dimaksud adalah reaksi antara gugus $\mathrm{OH}^{-}$dan krom, reaksi antara kation senyawa krom dan sulfat, reaksi dari masing-masing bahan misalnya formiat, reaksi antara protein kulit dan bahan senyawa.

Pada $\mathrm{pH}$ rendah maka konsentrasi $\mathrm{OH}^{-}$larutan relatif rendah dan basisitas krom juga rendah. Reaksi pertama menyebabkan kenaikan $\mathrm{pH}$ se-hingga reaksi ke kanan. Koordinasi ion-ion sulfat cenderung tidak dipengaruhi oleh $\mathrm{pH}$ dan ion sulfat akan masuk dalam senyawa kompleks pada $\mathrm{pH}$ rendah. Pembentukan ikatan koordinasi asam organik lemah atau masking agent dengan

Tabel 2. Hasil uji sifat kimia kulit jaket hasil penyamakan dengan krom hasil recovery.

\begin{tabular}{|c|c|c|c|c|}
\hline Parameter uji & Sampel & Hasil uji & Metode uji & $\begin{array}{l}\text { SNI Kulit jaket } \\
\text { domba/kambing }\end{array}$ \\
\hline \multirow[t]{5}{*}{ Kadar air, \% (b/b) } & 1 & 17,00 & \multirow[t]{5}{*}{ SNI 06-0644-1989 } & \multirow[t]{5}{*}{ Maks 18} \\
\hline & 2 & 17.00 & & \\
\hline & 3 & 17,00 & & \\
\hline & 4 & 16,98 & & \\
\hline & 5 & 16,99 & & \\
\hline \multirow{5}{*}{$\begin{array}{l}\text { Kadar krom oksida, } \\
\%(b / b)\end{array}$} & 1 & 3,56 & \multirow[t]{5}{*}{ SNI 06-0645-1989 } & \multirow[t]{5}{*}{$2,5-3,0$} \\
\hline & 2 & 3,60 & & \\
\hline & 3 & 3,36 & & \\
\hline & 4 & 3,34 & & \\
\hline & 5 & 3,49 & & \\
\hline \multirow[t]{5}{*}{ Kadar abu, $\%$ (b/b) } & 1 & 1,63 & \multirow[t]{5}{*}{ SNI 06-0564-1989 } & \multirow{5}{*}{$\begin{array}{l}\text { Maks, } 2 \% \text { di atas } \\
\text { kadar } \mathrm{Cr}_{2} \mathrm{O}_{3}\end{array}$} \\
\hline & 2 & 2,20 & & \\
\hline & 3 & 2,84 & & \\
\hline & 4 & 2,89 & & \\
\hline & 5 & 11,28 & & \\
\hline \multirow{5}{*}{$\begin{array}{l}\text { Kadar lemak/minyak, } \\
\%(\mathrm{~b} / \mathrm{b})\end{array}$} & 1 & 9,60 & \multirow[t]{5}{*}{ SNI -6-0564-1989 } & \multirow[t]{5}{*}{$8,0-15,0$} \\
\hline & 2 & 9,94 & & \\
\hline & 3 & 11,55 & & \\
\hline & 4 & 11,34 & & \\
\hline & 5 & 11,28 & & \\
\hline \multirow[t]{5}{*}{$\mathrm{pH}$} & 1 & 4,25 & \multirow[t]{5}{*}{ SNI ISO 4045-2011 } & \multirow[t]{5}{*}{$3,5-7,0$} \\
\hline & 2 & 4,23 & & \\
\hline & 3 & 4,27 & & \\
\hline & 4 & 4,25 & & \\
\hline & 5 & 4,06 & & \\
\hline
\end{tabular}

Keterangan kode sampel:

$1=$ Kulit jaket dengan konsentrasi $25 \%$ krom sulfat hasil recovery

$2=$ Kulit jaket dengan konsentrasi $50 \%$ krom sulfat hasil recovery

$3=$ Kulit jaket dengan konsentrasi $75 \%$ krom sulfat hasil recovery

$4=$ Kulit jaket dengan konsentasi 100\% krom sulfat hasil recovery

$5=$ Kulit jaket dengan konsentrasi $0 \%$ krom recovery (kontrol) 
senyawa krom kompleks, tergantung asam dan pH. $\mathrm{pH}$ tinggi akan menaikkan reaktivitas protein kulit, dan ionisasi tersebut menjadikan $\mathrm{pH}$ turun dan reaktifitas terhadap krom lebih kecil. Reaksi gugus karboksil pada protein sama dengan asam lemah tetapi cenderung lebih dipengaruhi oleh perubahan $\mathrm{pH}$ (Beltrán et al., 2011).

Menurut Garg et al. (2012), kenaikkan pH akan menaikkan basisitas senyawa krom kompleks (lebih banyak $\mathrm{OH}^{-}$yang masuk dalam kompleks). Dengan kenaikan nilai $\mathrm{pH}$, maka reaktivitas protein juga meningkat dan tahap awal penyamakan tercapai. Pada akhir kenaikan basisitas yang berarti basisitas tinggi dan ion sulfat sebagian sudah meninggalkan senyawa kompleks. Penggabungan senyawa krom kompleks secara sempurna dengan protein kulit akan menghasilkan ikatan silang (Belay, 2010). Dengan kenaikan basisitas, 2 senyawa krom saling bergabung antara satu dengan lainnya melalui gugus $\mathrm{OH}^{-}$.

Dalam penyamakan menggunakan senyawa krom maka reaksi dengan garam krom menjadi serat kulit sangat stabil dan tahan terhadap kerusakan oleh mikrobia dan suhu tinggi. Walaupun pemakaian garam krom dalam penyamakan kulit dapat mencemari lingkungan, namun terdapat kelebihan apabila penggunaan samak krom antara lain warna kulit lebih terang, kekuatan tarik lebih tinggi, mempunyai stabilitas yang baik terhadap bahan kimia, waktu penyamakan relatif singkat, tahan terhadap air dan pencucian, dan daya serap air dan udara cukup baik (Krishna, 2014).

\section{Hasil Uji Morfologi Kulit}

Morfologi kulit dapat dilihat berdasarkan hasil uji SEM. SEM merupakan mikroskop elektron yang dapat digunakan untuk mengamati morfologi permukaan skala mikro dan nano. Teknik analisis SEM menggunakan elektron sebagai sumber pencitraan dan medan elektromagnetik sebagai lensanya (Rianita et al., 2014).

Hasil uji SEM dari kulit jaket yang disamak dengan konsentrasi berturut-turut 25, 50, 75, dan $100 \%$ krom sulfat hasil recovery dapat dilihat pada Gambar 2. Sifat morfologi kulit jaket kambing hasil penyamakan dengan variaasi konsentrasi senyawa krom hasil recovery melalui uji SEM menunjukkan bahwa penggunaan senyawa krom hasil recovery konsentrasi 25\% maka serat kulit vertikal terlihat kuat karena bereaksi dengan senyawa krom. Hal ini menunjukkan bahwa konsentrasi $25 \%$ pemakaian krom sulfat olahan serat
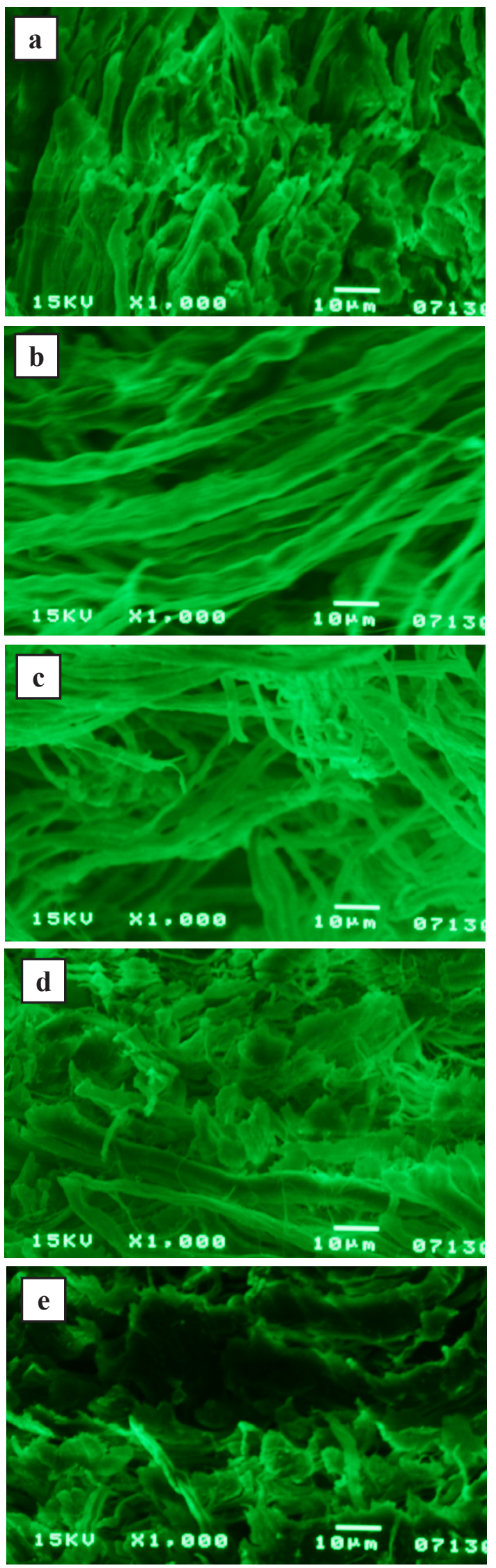

Gambar 2. SEM kulit jaket tersamak dengan krom hasil recovery sebesar (a) 25\%, (b) $50 \%$, (c) $75 \%$, (d) $100 \%$, dan (e) $0 \%$ (kontrol). 
kulit dan krom masih baik dan kuat. Sedangkan penggunaan krom recovery sebesar 50\% menunjukkan bahwa warna lebih terang karena penggunaan krom recovery lebih banyak, dan serat kulit masih kuat dan panjang. Pada penggunaan krom recovery konsentrasi $75 \%$ menunjukkan warna lebih terang karena penggunaan senyawa krom makin banyak dan kemungkinan kandungan $\mathrm{Cr}_{2} \mathrm{O}_{3}$ kulit makin berkurang, dan serat kulit masih terlihat kuat. Sedangkan penggunaan krom recovery sebesar $100 \%$, warna kulit cukup terang dan serat kulit masih kuat. Pada penyamakan tanpa krom recovery maka warna lebih gelap dan serat kulit tampak padat. Dengan demikian dapat disimpulkan bahwa penggunaan krom recovery tidak mempengaruhi mutu serat kulit.

Penggunaan senyawa krom komplek secara sempurna dengan protein kulit menghasilkan ikatan silang. Dengan naiknya basisitas maka 2 senyawa krom saling bergabung antara satu dengan lainnya melalui gugus $\mathrm{OH}^{-}$. Selain basisitas maka mutu bahan penyamak dalam bentuk senyawa krom dapat dipengaruhi oleh kadar krom yang lazim digunakan (Mukherjee, 2012).

Sifat dari larutan krom adalah sebagai berikut: dalam larutan pekat molekulnya kecil, sehingga penetrasinya mudah; dalam larutan encer molekulnya besar, sehingga penetrasinya sukar; pada basisitas rendah daya ikat (fiksasi) rendah; pada basisitas tinggi daya ikat (fiksasi) tinggi; pada basisitas rendah mudah larut dan pada basisitas tinggi akan mengendap ( $E l$-Sabbagh et al., 2011). Dengan demikian karena penggunaan krom sulfat yang lebih encer maka daya ikat rendah.

\section{KESIMPULAN}

Dari hasil uji sifat fisis, kimia dan morfologik kulit yang disamak dengan krom hasil recovery tidak berbeda jauh dengan penggunaan krom murni/puder krom. Penggunaan krom hasil recovery untuk sifat fisis terbaik adalah variasi 75 dan $100 \%$. Sedangkan untuk sifat kimia terbaik adalah penggunaan variasi krom recovery sebanyak $25 \%$, karena semua parameter memenuhi SNI 4593:2011. Hasil uji morfologi kulit dari uji SEM semua variasi masih terlihat serat kulit dan krom yang berikatan.

\section{UCAPAN TERIMA KASIH}

Penulis mengucapkan terima kasih kepada Kepala Balai Besar Kulit, Karet, dan Plastik atas fasilitas yang diberikan selama penelitian ini dan kepada semua fihak yang membantu terselesaikannya tulisan ini.

\section{DAFTAR PUSTAKA}

Belay, A. A. (2010). Impacts of chromium from tannery effluent and evaluation of alternative treatment options. Journal of Environmental Protection, 1(1), 53-58.

Beltrán-Prieto, J. C., Veloz-Rodríguez, R., Pérez-Pérez, M. C., Navarrete-Bolaños, J. L., Vázquez-Nava, E., Jiménez-Islas, H., \& Botello-Álvarez, J. E. (2012). Chromium recovery from solid leather waste by chemical treatment and optimisation by response surface methodology. Chemistry and Ecology, 28(1), 89-102.

Bestawy, E. L. E., Al-Fassi, F., \& Aburokba, R. A. R. (2013). Biological treatment of leather tanning industrial wastewater using free living bacteria. $\mathrm{Ad}$ vances in Life Science and Technology, 12, 46-65.

BSN (Badan Standardisasi Nasional). (2011). Standard Nasional Indonesia SNI 4593:2011: Kulit jaket domba/kambing, Jakarta, Indonesia: BSN.

Christianna, R., Samudro, G., \& Handayani, D. S. (2013). Studi penurunan konsentrasi kromium dan seng dalam limbah cair elektroplating artificial dengan metoda elektrokoagulasi. Jurnal Teknik Lingkungan, 2(3), 1-6.

Dettmer, A., Nunes, K., Gutterres, M., \& Marcilio, N., (2010). Tanning using basic chrome sulfate obtained from SASH produce in the thermal treatment of leather wastes. JALCA, 105(9), 280288.

El-Sabbagh, S. H., \& Mohamed, O.A. (2011). Recycling of chrome-tanned leather waste in acrylonitrile butadiene rubber. Journal of Applied Polymer Science, 121(2), 979-988.

Fuck, W. F., Gutterres, M., Marcílio, N. R., \& Bordingnon, S. (2011). The influence of chromium supplied by tanning and wet finishing processes on the formation of $\mathrm{Cr}(\mathrm{VI})$ in leather. Brazilian Journal of Chemical Engineering, 28(2), 221228.

Garg, S. K., Manikant, T., \& Thirureelakantan, S. (2012). Strategies for chromium bioremidiation of tannery effluent. Review of Environmental Contamination and Toxicology, 217, 75-140.

Harmami, H., Ulfin, I., \& Setyowuryani, R. (2014). Penurunan kadar kromium dari limbah cair industri penyamakan kulit dengan metode elektrokoagulasi. Dalam Prosiding Seminar Nasional Kimia, Surabaya, Indonesia: Jurusan Kimia FMIPA, Universitas Negeri Surabaya.

Hastutiningrum, S. (2010). Studi recovery krom (III) dari limbah cair penyamakan kulit dengan metode pengendapan (Disertasi). Universitas Gajah Mada, 
Indonesia.

Hyder, A. H. M. G. (2013). Sorption characteristics of hexavalent chromium [Cr(VI)] on to bone char and bio-char. TRITA-LWR Degree Project, 13, 09-47.

Krishna, M. S. (2014). Studies on treatment and reuse of tannery waste water by embedded system (Thesis). Anna University, India.

Ludvík, J. (2000). Chrome balance in leather processing. Vienna, Austria: United Nations Industrial Development Organization.

Mukherjee, G. (2012). Modification of chrome tanned waste with epichlorohydrin. Journal of Indian Leather technologists Association, 62(10), 902908.

Mutlu, M. M., Crudu, M. S., Maier, S., Deselnicu, D., Albu, L., Gulumser, G., Oral, B., Basaran, B., Tosun, C. C., \& Zengin, A. C. A. (2014). Ecoleather: Properties of chromium-free leathers produced with titanium tanning materials obtained from the wastes of the metal industry. Ekoloji, 23(91), 83-90.
Rianita, Y., Chomsin, S., Widodo, W., \& Masruroh, M. (2014). Studi identifikasi komposisi obat dan limbah balur benzoquinon (bq) hasil terapi pembaluran dengan scanning electron microscopy (SEM). Physics Student Journal, 2(1), 42-47.

Sundar, V. J. (2011). Recovery and utilization of chromium-tanned proteinous wastes of leather making: A review. Critical Reviews in Environmental Science and Technology, 41(22), 2048-2075.

Sutyasmi, S., \& Supraptiningsih, S. (2014), Pemanfaatan kembali krom limbah shaving untuk penyamakan kulit. Majalah Kulit, Karet, dan Plastik, 30(2), 87-93.

Wardhani, E., Dirgawati, M., \& Valyana, K. P. (2012). Penerapan metode elektrokoagulasi dalam pengolahan air limbah industri penyamakan kulit. Dalam Seminar Ilmiah Nasional Penelitian Masalah Lingkungan di Indonesia. Yogyakarta, Indonesia: Universitas Gadjah Mada. 